\title{
Formulasi Pertanggungjawaban Pidana Korporasi Menurut Undang-Undang Nomor 22 Tahun 2009 Terhadap Kecelakaan Lalu Lintas
}

\author{
Johanes Bornok Butar Butar1, Prija Djatmika², Yuliati ${ }^{3}$
}

${ }^{1}$ Fakultas HukumPascasarjana Universitas Brawijaya, E-mail: johanesbr@@gmail.com

2Fakultas Hukum Pascasarjana Universitas Brawijaya,E-mail: prija_djatmika@yahoo.com ${ }^{3}$ Fakultas Hukum, Universitas Brawijaya, E-mail: yuliaticholi1@ub.ac.id

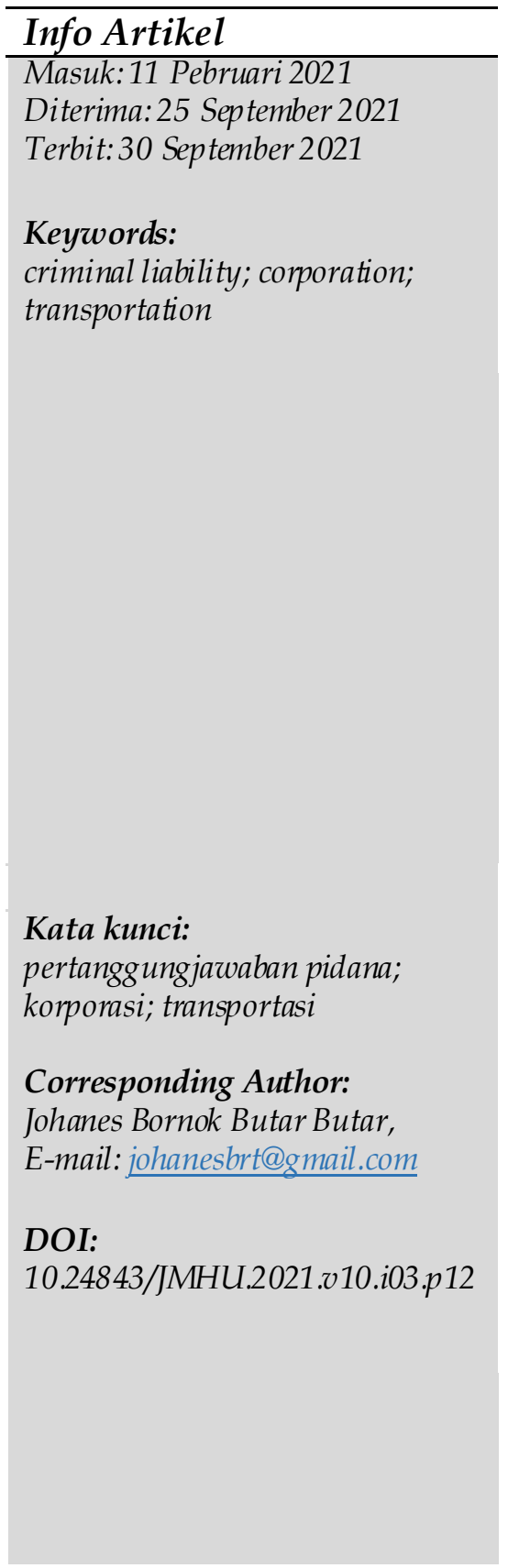

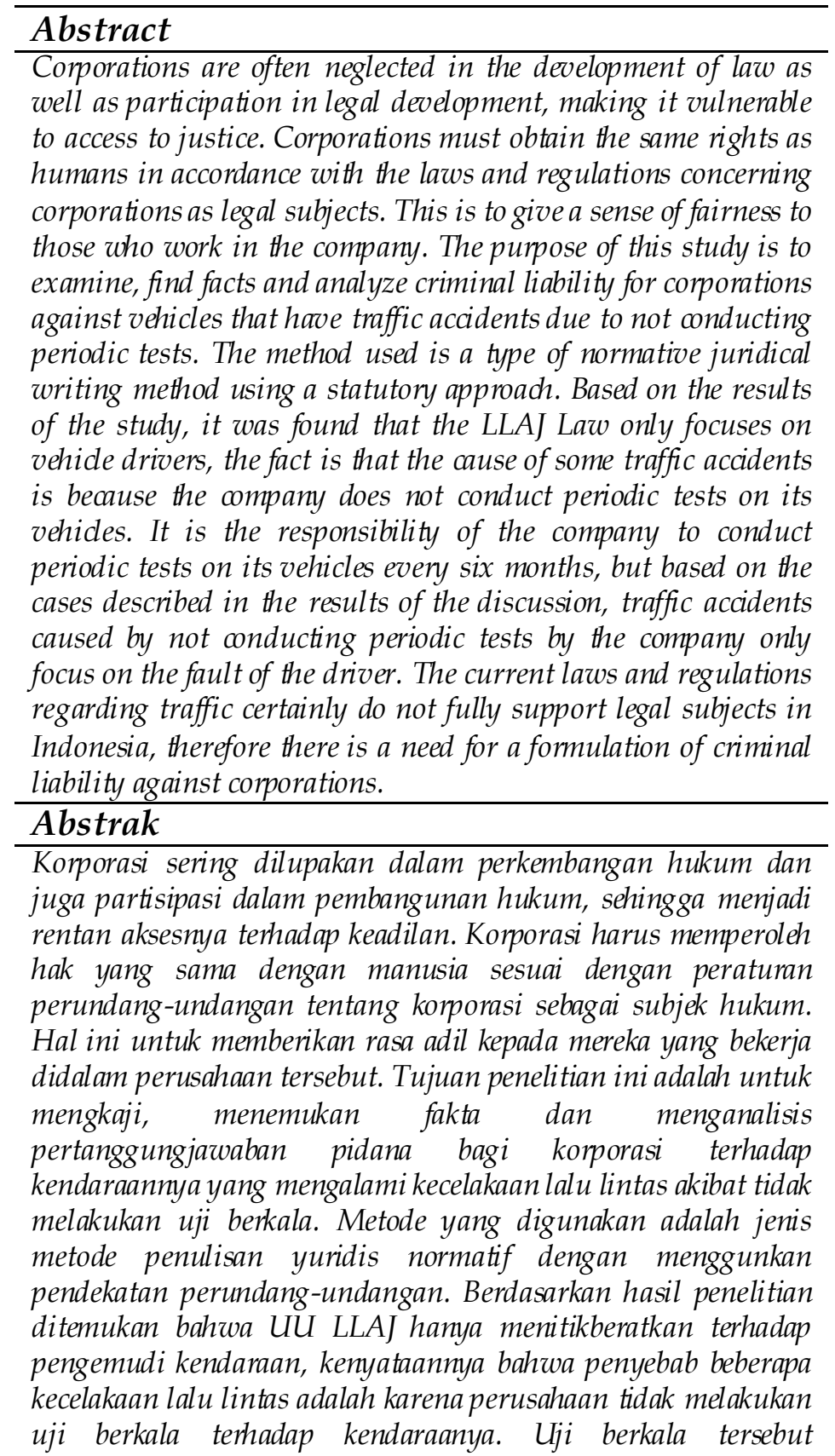


merupakan tanggungjawab dari perusahaan untuk melakukan pengujian secara berkala terhadap kendaraanya selama 6 bulan sekali, namun berdasarkan kasus yang diuraikan dalam hasil pembahsan, kecelakaan lalu lintas yang disebabkan karena tidak dilakukan uji berkala oleh perusahaan hanya menitikberatkan kesalahan terhadap pengemudi. Peraturan perundang-undangan tentang lalu lintas saat ini tentu sangat tidak mendukung sepenuhnya subjek hukum di Indonesia, oleh karena itu perlu adanya formulasi pertanggungjawaban pidana terhadap korporasi.

\section{Pendahuluan}

Badan Usaha atau Perusahaan di kalangan masyarakat dibagi dalam beberapa bentuk, yaitu badan usaha berbadan hukum dan badan usaha tidak berbadan hukum. Bentuk pengaturan dari badan-badan usaha tersebut diatur dalam Kitab UndangUndang Hukum Dagang (KUHD). Umumnya badan usaha baik yang berbadan hukum maupun yang tidak berbadan hukum disebut sebagai korporasi, korporasi dalam bahasa latin, secara subtansi (substantivum) berasal dari kata "corporare" yang terdiri dari kata "corpus" yang dalam bahasa Indonesia yang diartikan badan atau memberikan badan atau membadankan. ${ }^{1}$

Oleh karena badan hukum ini merupakan ciptaan hukum, maka kecuali penciptaannya, kematiannyapun ditentukan oleh hukum. Mengacu pada ketentuan Pasal 8 ayat (2) Reglement op de Burgerlijke Rechtsvordering, bahwa yang dimaksud dengan corporatie adalah sesuatu yang dapat disamakan dengan "person" yakni "rechtspersoon". 2

"The corporate crimes in all the time are growing and creating serious jeopardy to the concept of rule of law in Indonesia, the enforcement of authority of law, and justice are at stake. Corporations should not be separated from prosecution since the nature of crime is corporate crime by which the corporation crime performed only for the benefit of the corporation".3

Korporasi merupakan suatu badan hasil cipta hukum yang terdiri dari corpus, yaitu struktur fisiknya dan kedalam hukum memasukan unsur animus yang menghendaki badan tersebut mempunyai kepribadian, oleh karena itu badan hukum tersebut adalah ciptaan hukum, maka kecuali penciptaanya, kematiannya pun juga ditentukan oleh hukum. Menurut hukum ada dua subjek hukum yaitu:

\footnotetext{
${ }^{1}$ Hari Sutra Disemadi and Nyoman Serikat Putra Jaya, "Perkembangan Pengaturan Korporasi Sebagai Subjek Hukum Pidana Di Indonesia," Jurnal Hukum Media Bhakti, 2019, https://doi.org/https://doi.org/10.32501/jhmb.v3i2.38.

2 Umi Enggarsasi, "Pertanggung Jawaban Pidana Korporasi Dalam Kejahatan Ekonomi," Perspektif7, no.1 (2006): 20, https:// doi.org/10.30742/ perspektif.v7i1.368.

3 Fifid Bramita, "Corporate Criminal Liability On Criminal Actions in Consumer Protection," Jurnal Hukum Novelty 9, no. 2 (2018): 146.
} 
a. Manusia (naturlik person), artinya bahwa perbuatan seseorang atau orang (person) membawa hak dan kewajiban mulai dari dia dilahirkan sampai dia meninggal dunia, dan menimbulkan akibat hukum. ${ }^{4}$

b. Badan hukum (rechtpersoon), selain manusia, badan hukum juga memiliki hak dan kewajiban serta dapat melakukan perbuatan hukum seperti halnya manusia, badan hukum juga memiliki harta kekayaan sendiri. Selain itu badan hukum juga dapat dikenai pertanggungjawaban pidana, dan dapat juga digugat atau menggugat di pengadilan dengan perantaraan pengurusnya. ${ }^{5}$

Abidin menyatakan bahwa korporasi dipandang sebagai realitas sekumpulan manusia yang diberikan hak sebagai unit hukum, yang diberikan pribadi hukum, untuk tujuan tertentu. ${ }^{6}$ selanjutnya menurut Surbekti dan Tjitrosudibio corporatie atau korporasi adalah suatu perseroan yang merupakan badan hukum sedangkan Yan Pramadya Puspa menyatakan yang dimaksud dengan korporasi adalah suatu perseroan yang merupakan badan hukum ataupun yang bukan badan hukum. ${ }^{7}$ Jadi bahwa pengertian korporasi atau perseroan dapat diartikan sebagai perkumpulan atau organisasi yang oleh hukum diperlakukan seperti seorang manusia (persona) dan memiliki kewajiban hak menggugat ataupun digugat di muka pengadilan.

Berdasarkan dalam pengertian yang telah dijelaskan diatas, maka dapat diketahui bahwa selain korporasi dapat melakukan perbuatan hukum, korporasi juga dapat dikenai pertanggungjawaban pidana. Korporasi pada prakteknya dalam menjalankan aktifitasnya, tentu memerlukan sebuah transportasi mobil guna menstribusikan hasil produknya maupun bahan untuk membuat produk tersebut. Namun tidak menutup kemungkinan bahwa kendaraan milik korporasi atau perusahaan tersebut mengalami kecelakaan akibat tidak memenuhi uji berkala atau Kir.

Uji berkala kendaraan adalah suatu persyaratan yang harus dipenuhi oleh korporasi atau perusahaan terhadap kendaraannya, yang akan beroprasi dijalan raya melalui mekanisme pengujian pada kendaraanya agar tidak mengalami kegagalan sistem pengoprasian pada kendaraan. Sebagaimana yang telah diatur dalam Undang-Undang No. 22 Tahun 2009 tentang Lalu Lintas dan Angkutan Umum (selanjutnya disebut UU LLAJ), pada Pasal 53 UU LLAJ terkait dengan uji berkala menjelaskan secara singkat tentang uji berkala, yaitu:

1) Uji berkala sebagaimana dimaksud dalam Pasal 49 ayat (2) huruf b diwajibkan untuk mobil penumpang umum, mobil bus, mobil barang, kereta gandengan, dan kereta tempelan yang dioperasikan di jalan.

2) Pengujian berkala sebagaimana dimaksud pada ayat (1) meliputi kegiatan:

a. Pemeriksaan dan pengujian fisik kendaraan bermotor; dan

b. Pengesahan hasil uji

${ }^{4}$ Henry Donald Lbn Toruan, "Pertanggungjawaban Pidana Korupsi Korporasi," Jurnal Rechts Vinding: Media Pembinaan Hukum Nasional 3, no. 3 (2014): 397-416, https://doi.org/http://dx.doi.org/10.33331/rechtsvinding.v3i3.33.

5 Warih Anjari, "Pertanggungjawaban Korporasi Sebagai Pelaku Tindak Pidana," E-Journal Widya Yustisia 1, no. 2 (2018):116-21.

${ }^{6}$ Barda Nawawi Arief, Kebijakan Hukum Pidana (Jakarta: Kencana Prenadamedia, 2017).

7 Muladi \& Dwidja Priyatno, Pertanggungjawaban Pidana Korporasi, ke-3 (Jakarta: Kencana Prenada Media Group, 2015). 
3) Kegiatan pemeriksaan dan pengujian fisik kendaraan bermotor sebagaimana dimaksud pada ayat (2) huruf a dilaksanakan oleh:

a. Unit pelaksana pengujian pemerintah kabupaten/kota;

b. Unit pelaksana agen tunggal pemegang merek yang mendapat izin dari Pemerintah; atau

c. Unit pelaksana pengujian swasta yang mendapatkan izin dari Pemerintah.

Kenyataannya secara umum masih dapat ditemui beberapa perusahaan yang tidak melakukan uji berkala terhadap kendaraannya, yang akan beroprasi di jalan raya, padahal pengujian kendaraan yang tidak memenuhi persyaratan kelaikan kendaran saat beroprasi di jalan raya, sangat memiliki potensi tingkat kecelakaan yang tinggi dan banyaknya jumlah korban yang mengalami kecelakaan tersebut. Hal tersebut dikarenakan kendaraan yang saat itu beroprasi, bisa saja dapat mengalami kegagalan sistem pengoprasian seperti rem blong.

Sanksi terhadap tindak pidana kecelakaan lalu lintas pada umumnya diatur dalam Pasal 310 UU LLAJ, pun demikian dalam hal kecelakaan lalu lintas yang disebabkan oleh rem blong. Dalam ketentuan tersebut mengatur tentang sanksi pidana penjara yang diberikan terhadap pengemudi yang karena kelalaiannya menyebabkan matinya orang, maupun yang menyebabkan luka berat dan luka ringan di jalan raya. Adapun isi dalam ketentuan Pasal 310 UU LLAJ antara lain:

1) Setiap orang yang mengemudikan Kendaraan Bermotor yang karena kelalaiannya mengakibatkan Kecelakaan Lalu Lintas dengan kerusakan Kendaraan dan/atau barang sebagaimana dimaksud dalam Pasal 229 ayat (2), dipidana dengan pidana penjara paling lama 6 (enam) bulan dan/atau denda paling banyak Rp1.000.000,00 (satu juta rupiah).

2) Setiap orang yang mengemudikan Kendaraan Bermotor yang karena kelalaiannya mengakibatkan Kecelakaan Lalu Lintas dengan korban luka ringan dan kerusakan Kendaraan dan/atau barang sebagaimana dimaksud dalam Pasal 229 ayat (3), dipidana dengan pidana penjara paling lama (satu) tahun dan/atau denda paling banyak Rp2.000.000,00 (dua juta rupiah).

3) Setiap orang yang mengemudikan Kendaraan Bermotor yang karena kelalaiannya mengakibatkan Kecelakaan Lalu Lintas dengan korban luka berat sebagaimana dimaksud dalam Pasal 229 ayat (4), dipidana dengan pidana penjara paling lama 5 (lima) tahun dan/atau denda paling banyak Rp10.000.000,00 (sepuluh juta rupiah).

4) Dalam hal kecelakaan sebagaimana dimaksud pada ayat (3) yang mengakibatkan orang lain meninggal dunia, dipidana dengan pidana penjara paling lama 6 (enam) tahun dan/atau denda paling banyak Rp12.000.000,00 (dua belas juta rupiah).

Namun ketentuan Pasal 310 UU LLAJ yang saat ini berlaku hanya menitikberatkan pertanggungjawaban pidana terhadap sopir saja, sedangkan terhadap perusahaan atau pemilik kendaraan tidak dibebani tanggungjawab pidana. Tentu hal tersebut menjadi permasalahan yang mendasar terkait dengan pertanggungjawaban pidana koprorasi, mengingat bahwa pelaksanaan uji berkala adalah tanggungjawab perusahaan terhadap kendaraanya, sedangkan sopir dalam hal ini pengemudi kendaran dalam 
perusahaaan tersebut, tidak memiliki tanggungjawab terhadap pengujian berkala pada kendaraan.

Kecelakaan lalu lintas akibat tidak dilaksanakannya uji berkala, umumnya memiliki beberapa kriteria, yakni meledaknya ban pada kendaraan, kerusakan mesin yang menyebabkan pembuangan gas berlebihan, kebocoran pada oli kendaraan, kerusakan pada ban karena sudah gundul dan yang paling terkenal adalah rem blong pada kendaraan.

Uji berkala sendiri dilaksanakan oleh badan milik pemerintah, yakni Dinas Perhubungan sesuai dengan Pasal 55 UU LLAJ. Dalam penelitian ini penulis memberikan dua contoh kasus yang berkaitan dengan kecelakaan lalu lintas akibat tidak memenuhi uji kir, yang menyebabkan rem blong pada kendaraan. Dimana kedua kasus tersebut telah diputus oleh Pengadilan Negeri yang berwenang berdasarkan wilayahnya.

Kasus pertama terjadi pada tanggal 25 Agustus tahun 2017 tepatnya pada hari jumat sekitar pukul 16.45 Wib, dan telah diputus oleh Pengadilan Negeri Kepanjen dengan Nomor Perkara 739/Pid.Sus/2017/PN Kpn yang menyatakan sopir yaitu Iwan Prasetyo sebagai Tersangka dalam kecelakaan yang terjadi di jalan raya Karangploso. Kronologi terjadinya kecelakaan beruntun di jalan raya Karangploso tepatnya di Jl. Kertanegara Desa Grimoyo Kecamatan Karangploso Kabupaten Malang, dikarenakan sebuah truk Fuso Craine dengan No Pol N-9065-UA mengalami rem blong.

Pengemudi kendaraan saat itu setelah menyelesaikan tugas mengambil mesin kendaraan kemudian pulang menuju garasi Wijaya Putra dengan mengendarai mobil truk Fuso Craine dengan No Pol N-9065-UA, dan saat mobil truk tersebut berjalan dari arah Pendem berbelok ke kanan arah Karanglo (barat ke timur), pada saat yang demikian mesin mobil truk mengalami kerusakan, dimana pada pedal gas tidak berfungsi dengan baik yakni tekanan gas tinggi dan tidak bisa kembali ke standar, dan tidak lama setelah itu, terjadi permasalahan dengan sistem pengereman yang mana sistem pengereman tidak dapat difungsikan atau kegagalan sistem pengereman.

Hal yang demikian kemudian membuat rem tidak berfungsi, dan laju kendaraan tidak bisa dikendalikan oleh tersangka, setelah itu secara berturut-turut mobil truk No Pol N-9065-UA yang dikemudikan tersangka telah menabrak 11 (sebelas) sepeda motor, 2 (dua) mobil, 1 (satu) orang pejalan kaki, dan sebuah bangunan bengkel. Kelalaian yang menyebabkan matinya orang tersebut secara langsung bukan dari unsur kehendak atau kesengajaan yang dilakukan oleh Iwan, namun hal tersebut dikarenakan adanya kesalahan teknis pada sistem pengoprasian rem, dan menyebabkan rem pada kendaraan tidak berfungsi dan akhirnya mengalami rem blong.

Kasus kedua terjadi pada tanggal 26 Juli 2017, sekitar pukul 08.00 WIB atau setidaktidaknya pada bulan Juli tahun 2017, bertempat di jalan Raya Desa Mangliawan, Simpang tiga Industri Kecamatan Pakis, Kabupaten Malang telah diputus oleh Pengadilan Negeri Kepanjen dengan nomor perkara Nomor 866/Pid.Sus/2017/PN Kpn. Kronologi kejadian sebagai berikut, Semula pada hari waktu dan tempat sebagaimana disebutkan diatas terdakwa yang mengendarai Truck Tronton Hino dengan Nopol N 9041 UH dari garasi PT Wijaya Putra dari arah timur menuju ke arah barat dengan kecepatan kurang lebih $40 \mathrm{Km} /$ jam dan ketika sampai di simpang tiga industri Kecamatan Pakis ada petugas Supeltas yang memberhentikan kendaraan yang berjalan dari arah timur dengan jarak kurang lebih 100 (seratus) meter. 
Dengan maksud memeberikan kesempatan kendaraan yang dari arah barat untuk bergantian berjalan baik berjalan lurus maupun berbelok ke kanan, selanjutnya terdakwa berusaha menghentikan kendaraannya dengan menginjak rem namun rem dari kendaraan tersebut tidak berfungsi sehingga kendaraan truck tronton yang dikendarai oleh terdakwa tidak berhenti dan menabrak sepeda motor Honda Vario Nopol N 2691 GQ yang dikendarai oleh Sdri. SUYANTI dan sepeda motor Kawasaki Blitz Nopol N 6373 JF yang dikendarai oleh Sdr. INDRA PURWANTO yang membonceng Sdri. ENDIJAH LESTARI, yang berada didepannya.

Bahwa akibat dari tabrakan tersebut selain sepeda motor Honda Vario Nopol N 2691 GQ dan sepeda motor Kawasaki Blitz Nopol N 6373 JF yang mengalami kerusakan pada bagian bodi, Sdri. ENDIJAH LESTARI juga mengalami luka sebagaimana hasil Visum Et Repertum No.7/VER/RM/IX/17 tanggal 26 Juli 2017 dari Rumah Sakit Saiful Anwar yang ditandatangani oleh dr. DEDDE ADI YA RACHMAN.

Secara filosofis pemerintah dimungkinkan memperbesar pengaruhnya dalam kehidupan masyarakat, salah satu alatnya adalah dengan hukum pidana. ${ }^{8}$ Hukum pidana yang dimaksud adalah sanksi berupa ancaman hukuman pidana terhadap pelaku tindak pidana yang memenuhi unsur tindak pidana koporasi, yang menitikberatkan terhadap perusahaan yang kendaraannya mengalami kecelakaan akibat tidak dilakukannya uji berkala.

Masyarakat pada umumnya mengalami perkembangan dari tahun ke tahun, karena itu hukum pun harus mengikuti perkembangan masyarakat, agar masyarakat sendiri memperoleh jaminan, kepastian, keadilan, dan perlindungan hukum, khususnya yang berkaitan dengan kendaraan bermotor yang saat ini terus mengalami peningkatan pada jumlah transportasi kendaraan bermotor di Indonesia.

Berdasarkan penjelasan dari latar belakang di atas, maka tulisan ini memiliki tujuan untuk menjelaskan fenomena hukum terkait kekosongan hukum pengaturan perusahaan angkutan umum yang tidak berbadan hukum. Maka penulis melakukan penelitian dengan judul Formulasi Pertanggungjawaban Pidana Korporasi Menurut Undang-Undang Nomor 22 Tahun 2009 Serta Penerapannya Dalam Kecelakaan Lalu Lintas, dengan rumusan masalah: 1 . Apakah perusahaan sebagai pemilik kendaraan dapat dipertanggungjawabkan secara pidana jika kendaraannya mengalami kecelakaan lalu lintas akibat tidak melakukan uji kir? 2. Bagaimana Konstruksi pertanggungjawaban pidana Terhadap Korporasi yang berbentuk badan hukum dan tidak berbadan hukum dimasa depan?

Orsinalatas dalam penelitian ini yang terdapat dari penelitian-penelitian sebelumnya sebagai berikut: pertama dari jurnal pembangunan hukum Indonesia yang berjudul kebijakan formulasi pertanggungjawaban pidana korporasi terhadap perbuatan_trading in influence sebagai tindak_pidana korupsi, yang ditulis oleh Ratna Kumala Sari dan Nyoman Serikat Putra Jaya yang lebih menggambarkan formulasi pertanggungjawaban pidana korporasi melalui perbuatan trading in influence dalam tindak pidana korupsi. ${ }^{9}$ Kedua dari Jurnal hukum Samudra keadilan yang berjudul

${ }^{8}$ Arief Amrullah, Politik Hukum Pidana (Yogyakarta: Genta Publishing, 2016).

9 Ratna Kumala Sari and Nyoman Serikat Putra Jaya, "Kebijakan Formulasi Pertanggungjawaban Pidana Korporasi Terhadap Perbuatan Trading In Influence Sebagai Tindak Pidana Korupsi," Jurnal Pembangunan Hukum Indonesia 2, no. 1 (2020): 12-23, https://doi.org/https://doi.org/10.14710/jphi.v2i1.12-23. 
formulasi hukum pidana terkait pertanggung jawaban pidana korporasi dalam tindak pidana korupsi, yang ditulis oleh Yusi Amdani, yang mana lebih kepada formulasi pertanggungjawaban pidana korporasi dalam tindak pidana korupsi. ${ }^{10}$

\section{Metode Penelitian}

Metode penelitian dalam penelitian ini menggunakan jenis penelitian hukum normatif atau doktrinal. ${ }^{11}$ Artinya, penelitian hukum yag dilakukan dengan metode memilih bahan pustaka atau data sekunder.12 Peneltian hukum normatif atau kepustakaan terdiri dari penelaan terhadap azas hukum, sistematik hukum, dan terhadap taraf singkronisasi vertical dan horizontal, dimana ketentuan tersebut dibandingkan oleh sejarah hukum yang berada oleh negara yang menganut sistem hukum. ${ }^{13}$

Penelitian hukum normatif ini menggunakan metode perundang-undangan (statute approach), yaitu dengan cara menelaah semua peraturan perundang-undangan serta regulation yang terkait dengan permasalahan hukum yang sedang ada saat ini. ${ }^{14}$ Bahan dasar penelitian hukum normatiif, yaitu bahan hukum primer, bahan hukum sekunder dan bahan hukum tersier atau penunjang. ${ }^{15}$ Sumber bahan hukum primer yang penulis gunakan dalam penelitian hukum normatif ini, yaitu: Undang-Undang Nomor 22 Tahun 2009 tentang Lalu Lintas dan Angkutan Jalan, Peraturan Mahkamah Agung No. 13 Tahun 2016 tentang Tata Cara Penanganan Tindak Pidana oleh Korporasi, Putusan Pengadilan Negeri Kepanjen Nomor 739/Pid.Sus/2017/PN dan Putusan Pengadilan Negeri Kepanjen Nomor 866/Pid.Sus/2017/PN.

Bahan hukum sekunder yang penulis gunakan, yaitu terdiri dari buku-buku teks, jurnal hukum nasional atau internasional, teori-teori hukum dan Peraturan perundang-undangan yang berkaitan dengan korporasi. Dalam penelitian teknik pengumpulan dan analisis hukum dengan menggunakan mekanisme penggabungan bahan hukum yang dipakai, yaitu studi dokumentasi dengan mengumpulkan bahan yang terkait dengan hukum, berupa penelusuran buku terkait hukum dan catatan untuk memuat kutipan serta informasi lainnya yang dilakukan baik secara offline dan secara online. 16

\section{Hasil dan Pembahasan}

\subsection{Pertanggungjawaban pidana bagi perusahaan terhadap kendaraannya yang mengalami kecelakaan lalu lintas akibat tidak melakukan uji kir}

Masalah pertanggungjawaban pidana korporasi tentu tidak bisa dilepaskan dari tindak pidana, karena pada dasarnya korporasi merupakan subjek hukum pidana. Dalam

\footnotetext{
10 Yusi Amdani, "Formulasi Hukum Pidana Terkait Pertanggung Jawaban Pidana Korporasi Dalam Tindak Pidana Korupsi," Jurnal Hukum Samudra Keadilan 12, no. 2 (2017):186-98.

${ }_{11}$ Mahmud Marzuki, Penelitian Hukum (Jakarta: Prenada Media Group, 2015).

${ }^{12}$ Soejono Soekanto, Penelitian Hukum Normatif (Jakarta: Rajawali Pers, 2015).

13 Ibid. 14

${ }^{14}$ Mahmud Marzuki, Penelitian Hukum.

${ }^{15}$ Ibid. 38

16 I Made Pasek Diantha, Metodologi Penelitian Hukum Normatif Dalam Justifikasi Teori Hukum (Jakarta: Prenada Media Group, 2017).
} 
ilmu hukum pidana terdapat dua aliran yang membahas antara tindak pidana dengan pertanggungjawaban pidana. Aliran pertama adalah aliran monoistis yang memandang bahwa di dalam tindak pidana terkandung juga pertanggungjawaban, yang dimana unsurnya, yaitu: ${ }^{17}$

a. Perbuatan manusia (positif atau negatif; berbuat atau tidak berbuat atau membiarkan)

b. Diancam dengan pidana (strafbaar gesteld)

c. Melawan hukum (onrechmatig)

d. Dilakukan dengan kesalahan (met schuld in verband staand)

e. Oleh orang yang mampu bertanggung jawab (toerekenin svatbaar persoon)

Aliran kedua adalah aliran dualistis, dimana dasar aliran dualistis memaknai bahwa dalam istilah tindak pidana tidak termasuk di ketentuannya mengandung permasalahan pertanggunggjawaban, karena tindak pidana hanya mendasar pada larangan suatu hal perbuatan. ${ }^{18}$ Selain dari pada aliran yang telah dijelaskan diatas, adapun beberapa teori yang terkenal dalam memperkuat argument tentang pertanggungjawaban pidana korporasi, yaitu:

a. Teori identifikasi, memandang bahwa kondisi mental atau mens rea dari pengurus merupakan cerminan dari kondisi mental atau mens rea korporasi tersebut, sehingga unsur kesalahan yang ada pada pengurus merupakan unsur kesalahan yang ada pada korporasi tersebut. ${ }^{19}$

b. Vicarious liability, adalah suatu konsep pertanggungjawaban seseorang atas kesalahan yang dilakukan oleh orang lain, seperti tindakan yang dilakukan yang masih berada dalam lingkup pekerjaannya (the legal reponsibility of one person for wrongful acts of another, as for example, when the acts are done within scope of employment). .20

c. Teori aggregasi, yaitu Tindak pidana yang dilakukan seseorang digabungkan dengan kesalahan orang lain, atau adalah akumulasi kesalahan atau kelalaian yang ada pada diri tiap-tiap pelaku. ${ }^{21}$

d. Teori Delegasi adalah hasil dari penyempurnaan adanya teori identifikasi, dimana korporasi memiliki pengaruh besar terhadap hal yang menentukan

17 Rony Saputra, "Pertanggungjawaban Pidana Korporasi Dalam Tindak Pidana Korupsi," Jurnal Cita Hukum 3, no. 2 (2015), https:/ / doi.org/DOI: 10.15408/jch.v2i2.2318.

${ }^{18}$ Lukman Hakim, "Implementasi Teori Dualistis Hukum Pidana Di Dalam Rancangan Kitab Undang-Undang Hukum Pidana (RKUHP)," Krtha Bhayangkara 13, no. 1 (2019): 1-16, https://doi.org/https://doi.org/10.31599/krtha.v13i1.12.

19 Taun Taun, "Pertanggungjawaban Pidana Korporasi Dalam Tindak Pidana Ketenagakerjaan," Jurnal IUS Kajian Hukum Dan Keadilan 6, no. 2 (2018): 235-44, https://doi.org/http://dx.doi.org/10.29303/ius.v6i2.556.

20 Fines Fatimah, "Pertanggungjawaban Pengganti (Vicarious Liability) Dalam Kebijakan Formulasi Hukum Pidana Di Indonesia," LAW REFORM 7, no. 2 (2012): 1-42, https://doi.org/https://doi.org/10.14710/lr.v7i2.12408.

21 Puteri Hikmawati, "Kendala Penerapan Pertanggungjawaban Pidana Korporasi Sebagai Pelaku Tindak Pidana Korupsi (The Obstacles Of Implementing The Criminal Liability Of The Corporation As A Criminal Of Corruption)," Negara Hukum: Membangun Hukum Untuk Keadilan Dan Kesejahteraan 8, no.1 (2017):131-50, https:// doi.org/10.22212/jnh.v8i1.941. 
keputusan yang sifatnya fragmented. Subjek orang yang diketahui melakukan tindak pidana yang dapat dikenai tanggungjawab diluaskan cangkupannya, sepanjang pelaku tersebut melaksanakan keputusan dari korporasi.22

e. Untuk corporate culture model, pertanggungjawaban pidana dibebankan kepada korporasi bila berhasil ditemukan bahwa seseorang yang telah melakukan perbuatan melanggar hukum memiliki dasar yang rasional untuk meyakini bahwa anggota korporasi yang memiliki kewenangan telah memberikan wewenang atau mengizinkan dilakukannya tindak pidana tersebut. ${ }^{23}$

Indonesia merupakan negara yang banyak sekali didalamnya berdiri perusahaanperusahaan atau korporasi yang memiliki fungsi yang berbeda-beda, namun memiliki tujuan yang sama yaitu untuk pemenuhan kebutuhan ekonomi bagi masyarakat sebagai subjek hukum. ${ }^{24}$ Aktivitas perusahaan dalam melaksanakan fungsinya di masyarakat tentu membutuhkan peran dari adanya alat-alat penyokong untuk mempermudah aktivitasnya, yaitu kendaraan bermotor. Perusahaan angkutan umum pada umumnya memiliki kendaraan yang berfungsi untuk menyediakan angkutan orang maupun barang bagi perusahaan-perusahaan.

Namun berbeda halnya jika ada perusahaan yang memiliki kendaraan pribadi seperti truk, fuso atau kendaraan besar lainnya yang terpisah dari milik perusahaan angkutan umum. Perusahaan tersebut umumnya tidak menggunakan jasa dari perusahaan angkutan umum dalam mengkotribusikan hasil produk atau bahan milik perusahaannya, karena perusahaan tersebut memiliki kendaraan pribadi dalam melaksanakan kegiatannya. Dalam penelitian yang akan difokuskan pada penulisan ini, penulis akan berfokus terhadap perusahaan yang memiliki kendaraan pribadi.

Kendaraan pribadi yang dimiliki oleh perusahaan pada umumnya memiliki fungsi untuk mengkontribusikan maupun mengantarkan bahan-bahan yang dibutuhkan oleh perusahaannya, oleh karena itu penting bagi perusahaan untuk melakukan pengawasan terhadap kendaraan yang dimilikinya guna mengantisipasi terjadinya kerusakan pada kendaraan yang dapat menimbulkan kecelakaan. Pengawasan yang umumnya dilakukan oleh perusahaan adalah melalui pengecekan uji berkala pada kendaraannya yang dilaksanakan oleh Dinas Perhubungan di tiap-tiap kota atau kabupaten. 25

Kebijakan uji berkala kendaraan bermotor secara hukum diatur dalam UU LLAJ, Peraturan Menteri Perhubungan Republik Indonesia Nomor PM 133 Tahun 2015

22 Sudirman lu Feronica, "Lingkungan Dan Korupsi Korporasi," MIMBAR HUKUM Volume 23, no. 1 (2011), https:/ /doi.org/Doi:org/10.22146/jmh.16190.

23 Berinda Sylvia Raganatha, "Tinjauan Pertanggungjawaban Pidana Bagi Korporasi Yang Melakukan Insider Trading Dalam Pasar Modal," Refleksi Hukum: Jurnal Imu Hukum 2, no. 1 (2017): 17-32, https:/ /doi.org/https://doi.org/10.24246/jrh.2017.v2.i1.p17-32.

${ }^{24}$ Dyah Hapsari Prananingrum, “Telaah Terhadap Esensi Subjek Hukum: Manusia Dan Badan Hukum," Refleksi Hukum: Jurnal Ilmu Hukum 8, no. 1 (2014): 73-92, https://doi.org/https://doi.org/1024246/jrh.2014.v8.i1.p73-92.

25 Agung Santoso, "Analisis Kualitas Pelayanan Uji Kir Terhadap Kepuasan Masyarakat Pengguna Jasa Kir Di Dinas Perhubungan Kota Kediri," Jurnal Mediasosian: Jurnal Ilmu Sosial Dan Administrasi Negara 2, no. 11 (2018), https://doi.org/http://dx.doi.org/10.30737/mediasosian.v2i1 206. 
Tentang Pengujian Berkala Kendaraan Bermotor, dan Surat Keputusan Direktur Jenderal Perhubungan Darat dengan nomor SK.1131/AJ.003/DRJD/2003 telah mengacu pada Keputusan Menteri nomor 10 Tahun 1988, di mana dalam Surat Keputusan mengatur tentang standar pelayanan teknis mobil bus umum dari segi kelas pelayanan dan standar keselamatan. Kegiatan uji kelayakan operasional kendaraan bermotor diatur oleh UU LLAJ yang tercantum dalam Pasal 53 ayat 1 (satu) dan 2 (dua) serta pasal 54 yang menyatakan sebagai berikut:

Pasal 53

1. Uji berkala sebagaimana dimaksud dalam pasal 49 ayat (2) huruf b diwajibkan untuk mobil penumpang umum, mobil bus, mobil barang, kereta gandengan, dan kereta tempelan yang diperasikan di jalan

2. Pengujian berkala sebagaimana dimaksud pada ayat (1) meliputi kegiatan:

a. Pemeriksaan dan pengujian fisik kendaraan bermotor ; dan

b. Pengesahan hasil uji

Pasal 54

1. Pemeriksaan dan pengujian fisik mobil penumpang umum, mobil bus, mobil barang, kendaraan khusus, kereta gandengan, dan kereta tempelan sebagaimana dimaksud dalam pasal 53 ayat (2) huruf a meliputi pengujian terhadap persyaratan teknis dan laik jalan.

2. Pengujian terhadap persyaratan teknis sebagaimana dimaksud pada ayat (1) meliputi:
a. Susunan;
b. Perlengkapan;
c. Ukuran;
d. Karoseri;
e. Rancangan teknis kendaraan bermotor sesuai dengan peruntukannya

3. Pengujian terhadap persyaratan sebagaiman dimaksud pada ayat (1) sekurangkurangnya meliputi :
a. Emisi gas buang Kendaraan bermotor;
b. Tingkat kebisingan;
c. Kemempuan rem utama;
d. Kemampuan rem parkir;
e. Kincup roda depan;
f. Kemampuan pancar dan arah sinar lampu utama;
g. Akurasi alat penunjuk kecepatan, dan;
h. Kedalaman alur ban.

4. Pengujian terhadap persyaratan laik jalan kereta gan-dengan dan kereta tenpelan meliputi uji kemampuan rem, kedalaman alur ban dan uji sistem lampu 
5. Bukti lulus uji berkala hasil pemeriksaan dan pengujian fisik sebagaimana dimaksud pada ayat (1) berupa pemberian kartu uji dan tanda uji.

6. Kartu uji berkala sebagaimana dimaksud pada ayat (5) memuat keterangan tentang identifikasi kendaraan bermotor dan identitas pemilik, spesifikasi teknis, hasil uji, dan masa berlaku hasil uji.

7. Tanda uji berkala sebagaimana dimaksud pada ayat (5) memuat keterangan tentang identifikasi kendaraan bermotor dan masa berlaku hasil uji.

Berdasarkan kedua pasal diatas, maka dapat diketahui bahwa uji berkala wajib dilakukan oleh perusahaan yang memiliki kendaraan pribadi dalam melaksanakan kegiatannya menggunakan kendaraan tersebut. Kewajiban perusahaan dalam melaksanakan kegiatan pengujian berkala merupakan keharusan yang wajib dipenuhi oleh pemilik kendaraan, karena jikalau kendaraan tidak dilakukan uji berkala maka dikhawatirkan akan menimbulkan kerusakan mesin kendaraan dan berujung pada kecelakaan.

Kecelakaan lalu lintas akibat tidak dilakukannya uji berkala oleh perusahaan pemilik kendaraan pribadi, belum diatur dalam UU LLAJ. Pengaturan terkait sanksi pidana dalam UU LLAJ hanya menitikberarkan terhadap sopir dan perusahaan angkutan umum, sedangkan terhadap perusahaan yang memiliki kendaraan pribadi yang tidak mengandalkan jasa angkutan umum, tidak dapat dikenai sanksi pidana lantaran belum ada pengaturannya.

Perusahaan angkutan umum pada umumnya melaksanakan kegiatan dalam bidang angkutan umum seperti bus, kereta, angkutan kota/angkutan umum, elf, angkutan barang dan sebagainya yang melaksanakan kegiatan pengangkutan orang atau barang. ${ }^{26}$ Perusahaan yang melaksanakan kegiatannya dalam bidang penyedia produk kebutuhan sehari-hari, seperti perusahaan makanan ringan, perusahaan minuman, perusahaan rokok, perusahaan elektronik dan sebagainya, umumnya memiliki kendaraan pribadi dalam mengkontribusikan hasil produksinya, namun jika kendaranya mengalami kecelakaan lalu lintas akibat tidak dilakukan uji berkala, perusahaan pemilik kendaraan tersebut tidak dapat dikenai sanksi pidana. Tentu hal ini berbeda dengan perusahaan angkutan umum jikalau kendaraanya mengalami kecelakaan akibat tidak dilakukan uji berkala, dimana perusahaan angkutan umum dapat dikenai sanksi pidana. Hal ini dipertegas kembali dalam pasal 315 UU LLAJ yang menyatakan yaitu:

1) Dalam hal tindak pidana dilakukan oleh Perusahaan Angkutan Umum, pertanggungjawaban pidana dikenakan terhadap Perusahaan Angkutan Umum dan/atau pengurusnya.

2) Dalam hal tindak pidana lalu lintas dilakukan Perusahaan Angkutan Umum, selain pidana yang dijatuhkan terhadap pengurus sebagaimana dimaksud pada ayat (1), dijatuhkan pula pidana denda paling banyak dikalikan 3 (tiga) dari pidana denda yang ditentukan dalam setiap pasal dalam Bab ini.

26 Amirullah Amirullah, "Korporasi Dalam Perspektif Subyek Hukum Pidana," Al-Daulah: Jurnal Hukum Dan Perundangan Islam 2, no. 2 (2012): 139-60, https://doi.org/https://doi.org/10.15642/ad.2012.2.2.139-160. 
3) Selain pidana denda, Perusahaan Angkutan Umum dapat dijatuhi pidana tambahan berupa pembekuan sementara atau pencabutan izin penyelenggaraan angkutan bagi kendaraan yang digunakan.

Berdasarkan ketentuan pasal 315 UU LLAJ tentu perusahaan angkutan umum dapat dikenakan sanksi pidana, namun ketentuan diatas tidak berlaku terhadap perusahaan yang bukan merupakan perusahaan angkutan umum. Hal tersebut dapat diketahui dari belum adanya pengaturan terkait sanksi pidana bagi perusahaan atau korporasi yang kendaranya mengalami kecelakaan lalu lintas dalam UU LLAJ. Peraturan perundang-undangan terkait kecelakaan lalu lintas secara khusus diatur dalam UU LLAJ, namun pada penerapannya ternyata hal tersebut belum sempurna untuk dapat diterapkan bagi perusahaan atau korporasi yang memiliki kendaraan pribadi.

Terkait hal diatas, penulis akan memberikan dua contoh putusan Pengadilan Negeri terkait dengan penerapan sanksi pidana terhadap perusahaan yang bergerak dalam bidang angkutan barang yang bukan merupakan perusahaan angkutan umum. Putusan pertama telah diputus oleh Pengadilan Negeri Kepanjen dengan Nomor Perkara 739/Pid.Sus/2017/PN Kpn yang menyatakan sopir yaitu Iwan Prasetyo sebagai Tersangka dalam kecelakaan yang terjadi di jalan raya Karangploso.

Pengadilan Negeri Kepanjen dalam Nomor Perkara 739/Pid.Sus/2017/PN dalam amar putusannya menyatakan bahwa:

1. Menyatakan Terdakwa IWAN PRASETYO tersebut diatas, terbukti secara sah dan meyakinkan bersalah melakukan tindak pidana "Mengemudikan Kendaraan Bermotor Karena Kelalaiannya Mengakibatkan Orang Lain Meninggal Dunia, Mengakibatkan Orang Lain Luka-luka Dan Mengakibatkan Kerusakan Kendaraan Dan Barang" sebagaimana dalam dakwaan kumulatif;

2. Menjatuhkan pidana kepada Terdakwa oleh karena itu dengan pidana penjara selama 6 (enam) tahun dan denda sejumlah Rp1.000.000,00 (satu juta Rupiah) dengan ketentuan apabila Terdakwa tidak membayar denda tersebut maka diganti dengan pidana kurungan selama 2 (dua) bulan

Adapun dasar pertimbangan dari majelis hakim, yaitu Menimbang bahwa Terdakwa telah didakwa oleh Penuntut Umum dengan dakwaan kumulatif, maka Majelis Hakim terlebih dahulu mempertimbangkan dakwaan kesatu sebagaimana diatur dalam Pasal 310 ayat (4) UU Nomor 22 Tahun 2009 tentang Lalu Lintas dan Angkutan Jalan yang unsur-unsurnya adalah sebagai berikut:

1. Setiap Orang;

2. Mengemudikan Kendaraan Bermotor;

3. Karena Kelalaiannya Mengakibatkan Mengakibatkan Orang Lain Meninggal Dunia;

Berdasarkan unsur-unsur diatas Majelis Hakim mempertimbangkan sebagai berikut:

\section{Setiap Orang}

Bahwa yang dimaksud dengan "Setiap Orang" adalah siapa saja yang berkedudukan sebagai subyek hukum pendukung hak dan kewajiban dalam keadaan sehat jasmani dan rohani, serta memiliki kemampuan untuk bertanggung jawab atas segala perbuatan yang telah dilakukannya. 
Menimbang, bahwa berdasarkan uraian pertimbangan diatas, maka terhadap unsur "Setiap Orang" yang disandarkan kepada Terdakwa untuk memenuhi kapasitasnya sebagai subyek hukum dalam perkara ini secara yuridis formil telah terpenuhi, sehingga dengan demikian unsur "Setiap Orang", telah terpenuhi.

\section{Mengemudikan Kendaraan Bermotor}

Bahwa selanjutnya akan dibahas terlebih dahulu pengertian "Mengemudikan Kendaraan Bermotor" sebagai berikut: Menimbang, bahwa berdasarkan Pasal 1 angka 8 menyebutkan: “Kendaraan Bermotor adalah setiap kendaraan yang digerakkan oleh peralatan mekanik berupa mesin selain kendaraan yang berjalan diatas rel" dan Pasal 1 angka 22 menyebutkan: "Pengemudi adalah orang yang mengemudikan kendaraan bermotor di jalan yang telah memiliki Surat Izin Mengemudi". Menimbang, bahwa fakta hukum dalam persidangan menyebutkan pada hari Jumat tanggal 25 Agustus 2017 Terdakwa yang hanya memiliki SIM A mengendarai mobil truk Mitsubishi No Pol N-9065-UA Jl. Kertanegara Ds Girimoyo Kec Karangploso kab Malang. Menimbang, bahwa berdasarkan fakta hukum tersebut maka menjadi jelas ternyata benar Terd akwa memang mengemudikan kendaraan bermotor jenis mobil truk yang digerakkan oleh mesin berbahan bakar solar, dengan demikian unsur ini telah terpenuhi secara sah dan sempurna.

\section{Karena Kelalaiannya Mengakibatkan Mengakibatkan Orang Lain Meninggal Dunia}

Bahwa unsur ketiga ini berkaitan dengan perbuatan yang telah diuraikan pada unsur kedua diatas, sehingga yang yang harus dibuktikan dalam unsur ini adalah apakah benar Terdakwa kurang berhati-hati dalam mengemudikan kendaraan bermotor sehingga akibat perilakunya tersebut mengakibatkan orang lain meninggal dunia. Menimbang, bahwa fakta hukum dalam persidangan menyebutkan pada hari Jumat tanggal 25 Agustus 2017 Terdakwa yang hanya memiliki SIM A mengendarai mobil truk Mitsubishi No Pol N9065-UA dengan keadaan tidak memiliki Surat Tanda Uji Kendaraan, Plat uji habis masa dan tanda samping tidak terisi, filter mesin bocor, tangki bahan bakar tidak ada dan diganti jerigen plastik 30 liter, kondisi ban vulkanisir, tuas rem tangan tidak berfungsi sebab telah difungsikan sebagai alat operasi crane, melintas di Jl. Kertanegara Ds Girimoyo Kec Karangploso kab Malang dan pada saat berada dijalan tiba-tiba mobil truk yang dikemudikan Terdakwa tidak dapat dikendalikan dengan baik sehingga secara berturut turut mobil truk tersebut menabrak beberapa sepeda motor, menabrak beberapa mobil hingga rusak lalu menabrak rumah sehingga kendaraan bermotor dan bangunan rumah yang ditabrak tersebut rusak dan akibat kejadian tersebut juga telah mengakibatkan korban SUJATMIKO, korban KUSWANTO, korban WARSITI, korban AGUS SUPRIANTO dan korban WINARTI meninggal dunia.

Bahwa selanjutnya Majelis Hakim akan mempertimbangkan dakwaan kedua sebagaimana diatur dalam Pasal 310 ayat (2) UU Nomor 22 Tahun 2009 tentang Lalu Lintas dan Angkutan Jalan, yang unsur-unsurnya adalah sebagai berikut:

1. Setiap Orang; 
2. Mengemudikan Kendaraan Bermotor;

3. Karena Kelalaiannya Mengakibatkan Korban Luka;

Menimbang, bahwa setelah memperhatikan unsur-unsur diatas maka Majelis Hakim menilai unsur kesatu dan unsur kedua yang termuat dalam Pasal 310 ayat (2) UU Nomor 22 Tahun 2009 tentang Lalu Lintas dan Angkutan Jalan, memiliki kesamaan, maka untuk singkatnya Majelis Hakim mengambil alih pertimbangan unsur "Setiap Orang" dan unsur "Mengemudikan Kendaraan Bermotor" sebagaimana telah diuraikan dalam dakwaan kesatu tersebut diatas dan dianggap telah dipertimbangkan dalam uraian dakwaan kedua ini. Bahwa selanjutnya terhadap pertimbangan unsur ketiga sebagai berikut:

\section{Karena Kelalaiannya Mengakibatkan Korban Luka}

Bahwa fakta hukum dalam persidangan menyebutkan pada hari Jumat tanggal 25 Agustus 2017 Terdakwa yang hanya memiliki SIM A mengendarai mobil truk Mitsubishi No Pol N-9065-UA dengan keadaan tidak memiliki Surat Tanda Uji Kendaraan, Plat uji habis masa dan tanda samping tidak terisi, filter mesin bocor, tangki bahan bakar tidak ada dan diganti jerigen plastik 30 liter, kondisi ban vulkanisir, tuas rem tangan tidak berfungsi sebab telah difungsikan sebagai alat operasi crane, melintas di Jl. Kertanegara Ds Girimoyo Kec Karangploso kab Malang dan pada saat berada dijalan tiba-tiba mobil truk yang dikemudikan Terdakwa tidak dapat dikendalikan dengan baik sehingga secara berturut turut mobil truk tersebut menabrak beberapa sepeda motor, menabrak beberapa mobil hingga rusak lalu menabrak rumah sehingga kendaraan bermotor dan bangunan rumah yang ditabrak tersebut rusak dan akibat kejadian tersebut juga telah mengakibatkan korban DIDIK SATRIO NURDIN, korban ZAENAL ARIFIN, korban SILVI CHUMAIROTUN, korban INDAH RAHMAWATI, korban SYAHRUL ROMADHON, korban SUPRAPTO, korban S PRATOMO SIGIT, korban MAKOEN BK, korban SUPRAPTO, korban DEDY KRISTANTO, korban HERDINYANTO BEKTI UTOMO dan korban DELLA MEILINDA mengalami luka-luka.

Bahwa berdasarkan fakta hukum tersebut maka menjadi jelas dan dapat disimpulkan ternyata Terdakwa memang sama sekali tidak berhati-hati dalam mengendarai kendaraan bermotor sebab saat itu Terdakwa tidak pernah memeriksa dengan seksama kondisi kendaraan yang dikendarainya. Menimbang, bahwa oleh karena semua unsur dari Pasal 310 ayat (2) UU Nomor 22 Tahun 2009 tentang Lalu Lintas dan Angkutan Jalan telah terpenuhi, maka Terdakwa haruslah dinyatakan telah terbukti secara sah dan meyakinkan melakukan tindak pidana sebagaimana didakwakan dalam dakwaan kedua. Amar putusan dari putusan ini adalah sebagai berikut:

1. Menyatakan Terdakwa IWAN PRASETYO tersebut diatas, terbukti secara sah dan meyakinkan bersalah melakukan tindak pidana "Mengemudikan Kendaraan Bermotor Karena Kelalaiannya Mengakibatkan Orang Lain Meninggal Dunia, Mengakibatkan Orang Lain Luka-luka Dan Mengakibatkan Kerusakan Kendaraan Dan Barang" sebagaimana dalam dakwaan komulatif;

2. Menjatuhkan pidana kepada Terdakwa oleh karena itu dengan pidana penjara selama 6 (enam) tahun dan denda sejumlah Rp1.000.000,00 (satu juta Rupiah) dengan ketentuan apabila Terdakwa tidak membayar denda tersebut maka diganti dengan pidana kurungan selama 2 (dua) bulan; 
3. Menetapkan masa penahanan yang telah dijalani Terdakwa dikurangkan seluruhnya dari pidana yang dijatuhkan;

4. Menetapkan Terdakwa tetap dalam ditahan;

5. Membebankan kepada Terdakwa membayar biaya perkara sejumlah Rp2.000,00 (dua ribu Rupiah);

Putusan Kedua telah diputus oleh Pengadilan Negeri Kepanjen dengan Nomor Perkara Nomor 866/Pid.Sus/2017/PN Kpn yang menyatakan sopir yaitu Wahyu Purwo Prasetyo sebagai Tersangka dalam kecelakaan yang terjadi di jalan Raya Desa Mangliawan, Simpang tiga Industri Kecamatan Pakis, Kabupaten Malang Pengadilan Negeri Kepanjen dalam Nomor Perkara 866/Pid.Sus/2017/PN Kpn dalam amar putusannya menyatakan bahwa:

sebagaimana diatur dalam Pasal 310 ayat (2) UU RI No.22 tahun 2009 tentang Lalu Lintas dan Angkutan Jalan yang unsur-unsurnya adalah sebagai berikut:

1. Setiap orang;

2. Mengemudikan Kendaraan Bermotor yang karena kelalaiannya mengakibatkan kecelakaan lalu lintas dengan korban luka ringan dan kerusakan kendaraan;

Menimbang, bahwa terhadap unsur-unsur tersebut Majelis Hakim mempertimbangkan sebagai berikut;

1. Unsur Setiap orang

Menimbang, bahwa di persidangan telah dihadapkan oleh Penuntut Umum seorang laki-laki yang menyatakan bernama WAHYU PURWO PRASETYO dengan identitas lengkap sebagaimana termuat dalam surat dakwaan Penuntut Umum yang telah dibacakan di persidangan dan atas dibacakannya identitas Terdakwa tersebut Terdakwa membenarkannya. Menimbang, bahwa berdasarkan pertimbangan tersebut di atas, maka menurut Majelis Hakim unsur "Setiap orang" telah terpenuhi

2. Unsur Mengemudikan Kendaraan Bermotor yang karena kelalaiannya mengakibatkan kecelakaan lalu lintas dengan korban luka ringan dan kerusakan kendaraan

Menimbang, bahwa sebelum mempertimbangkan unsur tersebut, Majelis Hakim akan mendefinisikan terlebih dahulu hal-hal sebagai berikut:

a. Kendaraan bermotor adalah setiap kendaraan yang digerakkan oleh peralatan mekanik berupa mesin selain kendaraan yang berjalan di atas rel;

b. Kelalaian adalah suatu sikap kurang hati-hati atau sikap kurang cermat dalam melakukan sesuatu;

c. Kecelakaan Lalu Lintas adalah suatu peristiwa di Jalan yang tidak diduga dan tidak disengaja melibatkan Kendaraan dengan atau tanpa Pengguna Jalan lain yang mengakibatkan korban manusia dan/atau kerugian harta benda;

d. Luka ringan adalah adalah luka yang mengakibatkan korban menderita sakit yang tidak memerlukan perawatan inap di rumah sakit; 
Menimbang, bahwa pada hari Rabu tanggal 26 Juli 2017 sekitar 07.30 Wib bertempat di Jl. Raya Mendit Barat Desa Mangliawan Kecamatan Pakis Kabupaten Malang, telah terjadi kecelakaan lalu lintas antara truck tronton Nopol: N $9041 \mathrm{UH}$ yang dikemudikan oleh Terdakwa dengan pengendara sepeda motor Kawasaki Blit Nopol N-6373-JF dan dengan pengendara sepeda motor Honda Vario Nopol: N-2691-GQ;

Menimbang, bahwa kejadian tersebut terjadi bermula ketika ketika Terdakwa yang mengemudikan kendaraan truck tronton hino Nopol. : N 9041 UH yang berangkat menuju kantor DISHUB diDaerah Karang Ploso Malang untuk uji KIR yang berjalan dari arah Timur ke Barat, dan sesampainya di Jl . Raya Mangliawan tepatnya di Simpang tiga industri ada petugas Supeltas yang memberhentikan kendaraan yang berjalan dari arah Timur untuk memberi kesempatan kepada kendaraan yang berjalan dari arah Barat ke Timur.

Kemudian saat belok ke kanan, dan saat itu Terdakwa berusaha untuk berhenti dengan menginjak rem namun saat itu rem tidak berfungsi sehingga kendaraan truck hino yang dikemudikan Terdakwa tetap melaju dan akhirnya menabrak sepeda motor Honda Vario Nopol.: N-2691-GQ yang dikendarai oleh saksi Suyanti dan sepeda motor Kawasaki Blit Nopol.: N-6373-JF yang dikendarai oleh saksi Indra Purwanto yang berboncengan dengan saksi Endijah Lestari;

Menimbang, bahwa penyebab utama terjadinya kecelakaan lalu lintas tersebut dikarenakan rem yang tidak berfungsi pada kendaraan mobil truck tronton hino yang dikemudikan oleh Terdakwa, hal mana seharusnya sebelum mengemudikan kendaraan tersebut Terdakwa wajib mengecek kondisi kendaraan yang akan dikemudikannya termasuk dalam hal ini salah satu elemen yang penting pada setiap kendaraan adalah berfungsinya rem dengan baik, akan tetapi hal tersebut tidak dilakukan oleh Terdakwa, sehingga ketika Terdakwa berusaha untuk mengurangi maupun menghentikan laju kendaraannya Terdakwa tidak dapat menghentikan laju kendaraan yang dikemudikannya dikarenakan tidak berfungsinya rem yang pada akhirnya terjadilah kecelakaan tersebut.

Menimbang, bahwa berdasarkan pertimbangan tersebut di atas, maka menurut Majelis Hakim unsur kedua ini telah terpenuhi. Menimbang, bahwa oleh karena semua unsur dari Pasal 310 ayat (2) Undang-Undang Republik Indonesia Nomor 22 Tahun 2009 Tentang Lalu Lintas Dan Angkutan Jalan telah terpenuhi, maka Terdakwa haruslah dinyatakan telah terbukti secara sah dan meyakinkan melakukan tindak pidana sebagaimana didakwakan tersebut.

Pada bagian amar putusan, hakim menyatakan sebagai berikut:

1. Menyatakan Terdakwa WAHYU PURWO PRASETYO tersebut diatas, terbukti secara sah dan meyakinkan bersalah melakukan tindak pidana Mengemudikan Kendaraan Bermotor Yang Karena Kelalaiannya Mengakibatkan Kecelakaan Lalu Lintas Dengan Korban luka ringan dan kerusakan kendaraan sebagaimana dalam dakwaan tunggal Penuntut Umum;

2. Menjatuhkan pidana kepada Terdakwa oleh karena itu dengan pidana penjara selama 4 (empat) bulan; 
3. Membebankan kepada Terdakwa membayar biaya perkara sejumlah Rp2000,00 (duaribu Rupiah);

Berdasarkan contoh kasus diatas, maka dapat disimpulkan bahwa penerapan dalam UU LLAJ terhadap perusahaan atau korporasi belum sepenuhnya memberi pertanggungjawaaban pidana. Hal tersebut tentu berbeda dengan perusahaan angkutan umum, dimana sekalipun sopir yang mengemudikan kendaraan mengalami kecelakaan, namun jika penyebab kecelakaan tersebut disebabkan oleh perusahaan angkutan umum maka perusahaan angkutan umum dikenakan sanksi pidana berdasarkan pada Pasal 315 UU LLAJ.

Sedangkan terhadap perusahaan atau korporasi yang yang memiliki kendaraan pribadi belum memiliki kemungkungkinan dikenakan sanksi pidana, karena belum adanya pengaturan dalam UU LLAJ. Seperti yang diketahui bahwa korporasi adalah salah satu subjek hukum pidana, hal tersebut diperkuat dengan adanya teori terkait dengan korporasi, yaitu:

\section{Teori Vicarious liability}

Penerapan teori vicarious liability dalam kasus kecelakaan yang disebabkan oleh perusahaan yang tidak melakukan uji kir terhadap kendaraannya, merupakan konsep yang belum diterapkan secara menyeluruh dalam peraturan perundangundangan saat ini di Indonesia. ${ }^{27}$ Permasalahannya timbul ketika adanya keharusan dalam hal pembuktian bahwa kecelakaan tersebut merupakan akibat dari tidak dilakukanya uji kir oleh pemilik kendaraan atau perusahaan.

Disisi lain alat yang saat ini digunakan untuk melakukan pembuktian bahwa kecelakaan yang disebabkan karena tidak dilakukanya uji kir, belum sama sekali memiliki kepastian pembenaran yang mutlak, oleh karena itu hal tersebut membuat perusahaan tidak dapat dikenakan sanksi pidana. Kenyataannya, sudah banyak sekali kecelakaan lalu lintas yang timbul di Indonesia bersamaan dengan tidak dilakukanya uji kir atau terlambat dalam melakukan uji kir oleh pemilik kendaraan atau perusahaan. Berikut adalah beberapa contoh kasus kecelakaan lalu lintas bersamaan dengan tidak dilakukanya uji kir atau terlambat dalam melakukan uji kir oleh pemilik kendaraan atau perusahaan:

a. Kasus kecelakaan truk dump bermuatan pasir di Tol Cipularang yang disebabkan oleh rem blong, dimana akibat kecelakaan tersebut bersamaan dengan tidak di ujinya kir pada kendaraan.

b. Kasus Kecelakaan di jalan Raya Bogor, Kampung Sampay, Desa Tugu Utara, Kecamatan Cisarua, Kabupaten Bogor, Jawa Barat. Dimana kecelakaan tersebut disebabkan oleh rem blong yang disebabkan karena tidak dilakukannya uji kir oleh pemilik kendaraan.

c. Truk tronton maut yang menyebabkan kecelakaan beruntun di Jalan Veteran, Gresik, dimana kecelakaan tersebut diduga akibat tidak dilakukannhya uji kir selama 6 tahun.

27 Dalinama Telaumbanua, "Pertanggungjawaban Pidana Korporasi Di Bidang Lingkungan Hidup," Refleksi Hukum: Jurnal Ilmu Hukum 9, no. 1 (2015): 101-12, https://doi.org/https:/ /doi.org/1024246/jrh.2015.v9.i1.p101-112. 
d. Bus PO Sriwijaya yang mengalami kecelakaan maut di Pagar Alam, Sumatera Selatan dan terakhir kali menjalani uji kir dua tahun yang lalu.

Permasalahan ini tentu membuat kinerja dari peraturan perundang-undangan tidak dapat bekerja secara menyeluruh atau adil terhadap penerapannya, khususnya terkait kecelakaan lalu lintas yang disebabkan karena tidak dilakukannya uji kir oleh perusahaan pemilik kendaraan.

Teori vicarious liability dalam penerapannya didalam kasus kecelakaan lalu lintas yang disebabkan karena tidak dilakukannya uji kir oleh perusahaan, memang belum tercermin, namun seharusnya dapat dijadikan dasar dan pertimbangan oleh hakim atau penegak hukum lainnya dalam mengambil keputusan terkait permasalahn diatas. ${ }^{28}$ Hal ini dapat membuktikan bahwa adanya teori vicarious liability dalam aktivitas perusahaan atau korporasi, mengartikan bahwa perusahaan pemilik kendaraan yang tidak melakukan uji kir terhadap kendaraannya dan karena perbuatannya menyebabkan kecelakaan, dapat dikenakan sanksi terhadap perusahaan sebagai pemilik kendaraan tersebut.

\subsection{Konstruksi pertanggungjawaban pidana Terhadap Korporasi yang berbentuk badan hukum dan tidak berbadan hukum dimasa depan}

Pengertian dari Kontruksi Hukum adalah mekanisme dalam membentuk dan menelah kekosongan yang ada pada suatu produk hukum yang berlandaskan azas-azas dan pondasi hukum. Pengkonstruksian tersebut berasal dari beberapa bentuk, yaitu logika, Determination dan ArgumentasiAcontrario. ${ }^{29}$ Umumnya hal ini diterapkan oleh hakim melalui Interpretasi (Penafsiran) berdasarkan kewenangan yang dimilikinya. Namun guna memperoleh keyakinan dan kepastian hukum, tentu hal tersebut tidak layak jika dipergunakan terus menerus, oleh karena itu perlu adanya peran dari pembentuk peraturan perundang-undangan untuk mengisi kekosongan hukum tersebut. Adapun dua cara atau mekanisme untuk mengatasi hal tersebut, yang mana hal tersebut diperlukan peran dari Dewan Perwakilan Rakayat atau pembentuk undang-undang, yaitu:

\section{Menerapkan makna Korporasi sebagai Badan hukum dan Bukan Badan Hukum Dalam UU LLAJ}

Seperti yang diketahui pada pembahasan sebelumnya bahwa Peraturan PerundangUndangan yang mengatur tentang ketentuan pidana korporasi, dan Peraturan Mahkamah Agung No. 13 Tahun 2016 serta Putusan Mahkamah Agung Nomor 2239 K/PID.SUS/2012 menerapkan makna korporasi sebagai badan hukum dan bukan badan hukum dalam penjelasnnya. Tentu ini berbanding teerbalik dengan ketentuan dalam UU LLAJ yang mana dalam ketetntuan Pasal 1 angka (21) UU LLAJ sendiri menyatakan bahwa "Perusahaan Angkutan Umum adalah badan hukum yang menyediakan jasa angkutan orang dan/atau barang dengan Kendaraan Bermotor Umum".

28 Budi Suhariyanto, "Putusan Pemidanaan Terhadap Korporasi Tanpa Didakwakan Dalam Perspektif "Vicarious Liability"," Jurnal Yudisial 10, no. 1 (September 8, 2017): 17-38, https://doi.org/1029123/JY.V1011.68.

${ }^{29}$ Enju Juanda, "Konstruksi Hukum Dan Metode Interpretasi Hukum," Jurnal Ilmiah Galuh Justisi 4, no. 2 (2017): 168, https://doi.org/10.25157/jigj.v4i2.322. 
Menurut Garner dan Bryan A, mengemukakan bahwa pengertian korporasi diambil dari istilah dalam bahasa Inggris "Corporation" yang berarti badan hukum atau bukan berbadan hukum yang oleh Undang-Undang diperbolehkan untuk melakukan perbuatan sebagaimana seorang individu sebagai subjek hukum, berbeda dengan para pemegang sahamnya. ${ }^{30}$

Sedangkan secara luas sebagai pengertian korporasi dalam hukum pidana, Sutan Remi mendefinisikan korporasi sebagai berikut: "Dalam hukum pidana, korporasi meliputi baik badan hukum maupun bukan badan hukum, bukan saja badan-badan hukum seperti perseroan terbatas, yayasan, koperasi atau perkumpulan yang telah disahkan sebagai badan hukum yang digolongkan sebagai korporasi menurut hukum pidana, tetapi juga firma, persekutuan komanditer atau CV, dan persekutuan atau maatschap, yaitu badan-badan usaha yang menurut hukum perdata bukan suatu badan hukum". ${ }^{31}$

\section{Memformulasikan Pertanggungjawaban Pidana Dalam UU LLAJ Terhadap Perushaan Angkutan Umum Yang Bukan Berbadan Hukum}

Pada dasarnya dapat diketahui beberapa hal yang tentunya dilengkapi untuk adanya pertanggungjawaban korporasi, yaitu: 32
a. Pengurus korporasi sebagai pembuat dan sebagai penaggung jawab.
b. Korporasi sebagai pembuat dan pengurus sebagai penaggung jawab.
c. Korporasi sebagai pembuat dan juga sebagai penanggung jawab.

Perusahaan angkutan umum sendiri merupakan bagian dari korporasi yang memiliki tugas untuk melakukan pengangkutan. Secara teoritik, pengangkutan memiliki arti terkait dengan angkutan barang atau individu yang melakukan aktifitas angkutan dan pengiriman barang, atau orang yang melakukan kegiatan angkutan, artinya didalam pemahaman terkait dengan angkutan itu tersirat suatu mekanisme kegiatan atau perpindahan dari satu lokasi ke lokasi lainnya.33 Berdasarkan artian tersebut perusahaan angkutan umum, memilikki beberapa alur yang terdiri sebagai berikut:

a. Individu, yaitu orang yang aktifitasnya terhubung dengan hal angkutan, yang dapat terdiri dari badan usahaatau perorangan.

b. Alat pengangkutan, adalah sebuah benda yang difungsikam sebagai penyelenggaraan angkutan, seperti mobil roda empat atau lebih.

c. Barang atau penumpang, yaitu muatan yang diangkut.

${ }^{30}$ I.F Putri, F.R., Lie, H., \& Tanlilessy, “Tindak Pidana Penyuapan Oleh Korporasi Dari Sudut Pandang Teori Identifikasi," Jurnal Hukum Pidana Islam 6, no. 1 (2020), https://doi.org/doi:org/10.15642/aj.2020.6.1.202-228.

31 Kristian Kristian, "Urgensi Pertanggungjawaban Pidana Korporasi," Jurnal Hukum \& Pembangunan 44, no. 4 (December 26, 2014): 575-621, https://doi.org/10.21143/JHP.VOL44.NO4.36.

32 A A Ngurah Wirajaya et al., "Asas Tiada Pidana Tanpa Kesalahan (Asas Kesalahan) Dalam Hubungannya Dengan Pertanggungjawaban Pidana Korporasi," Jurnal Kertha Negara 1, no. 3 (2013): 1-5, https:// doi.org/Doi.org/1029123/jym.v20i1.05.

33 Febri Yuliani et al., "Penyelenggaraan Angkutan Orang Dengan Kendaraan Umum Di Surabaya Implementation of Passenger Transport with Public Transport in Surabaya," Jurnal Manajemen Transportasi Dan Logistik 2, no. 2 (2017):169. 
d. Aktifitas, yaitu kegiatan mengangkut barang dan/atau orang sejak pemuatan sampai dengan penurunan di tempat tujuan sesuai dengan yang telah ditentukan/diperjanjikan.

Perusahaan angkutan umum dalam melakukan aktifitasnya, secara langsung diakui sebagai korporasi yang berbadan hukum atau yang bukan berbadan hukum. Oleh karena itu perusahaan angkutan umum secara umum memenuhi unsur-unsur dalam pertanggungjawaban korporasi, namun pada prakteknya dalam ketentuan UU LLAJ, pengaturan tersebut tidak tercantum terkait dengan perusahaan angkutan umum yang bukan berbadan hukum.

Ketetntuan pidana terhadap perusahaan angkutan umum sendiri diatur dalam Pasal 315 UU LLAJ, yang menyatakan sebagi berikut:

a. “Ayat (1) Dalam hal tindak pidana dilakukan oleh Perusahaan Angkutan Umum, pertanggungjawaban pidana dikenakan terhadap Perusahaan Angkutan Umum dan/atau pengurusnya".

b. “Ayat (2) Dalam hal tindak pidana lalu lintas dilakukan Perusahaan Angkutan Umum, selain pidana yang dijatuhkan terhadap pengurus sebagaimana dimaksud pada ayat (1), dijatuhkan pula pidana denda paling banyak dikalikan 3 (tiga) dari pidana denda yang ditentukan dalam setiap pasal dalam Bab ini".

c. "Ayat (3) Selain pidana denda, Perusahaan Angkutan Umum dapat dijatuhi pidana tambahan berupa pembekuan sementara atau pencabutan izin penyelenggaraan angkutan bagi kendaraan yang digunakan".

Pada ketentuan tersebut dapat diketahui bahwa perusahaan angkutan umum dapat dipertanggungjawabkan dalam pasal 315 UU LLAJ, namun pada ketentuan umum Pasal 1 angka (21) UU LLAJ sendiri menyatakan bahwa "Perusahaan Angkutan Umum adalah badan hukum yang menyediakan jasa angkutan orang dan/atau barang dengan Kendaraan Bermotor Umum". Artinya bahwa perusahaan angkutan umum yang berbadan hukum saja yang dapat dikenakan pasal 315 UU LLAJ, sedangka perusahaan angkutan umum yang bukan berbadan hukum tidak dapat dipertanggungjawabkan lantaraan belum ada ketentuannya dalam UU LLAJ.

Ketentuan dalam UU LLAJ tentu dalam hal ini perlu diformulasikan kembali, mengingat bahwa transportasi merupakan kebutuhan primer, khusunya yang pekerjaanya berkaitan dengan transportasi. Oleh karena itu pemerintah diharapkan dapat merevisi kembali UU LLAJ, kshusnya ketentuan umum Pasal 1 UU LLAJ yang menafsirkan perusahaan angkutan umum sebagai perusahaan yang berbadan hukum dan bukan berbadan hukum.

\section{Kesimpulan}

Pertanggungjawaban pidana bagi perusahaan terhadap kendaraannya yang mengalami kecelakaan lalu lintas akibat tidak melakukan uji kir, dapat diketahui bahwa secara hukum dan berdasarkan dua contoh kasus diatas, korporasi yang memiliki kendaraan yang mengalami kecelakaan karena tidak dilakukan uji kir terhadap korporasi tidak dapat dipidana karena belum ada pengaturannya. Gagasan yang menyatakan bahwa korporasi dapat dipertanggungjawabkan dapat diperkuat dengan adanya teori Vicarious liability, yang mana teori ini menyatakan bahwa 
korporasi yang memiliki kendaraan yang mengalami kecelakaan karena tidak dilakukan uji kir seharusnya dapat dipidana.

Selain itu guna untuk memberikan kepastian dan mengisi kekosongan hukum terhadap pertanggungjawban pidana korporasi, maka perlu adanya regulasi dalam memformulasikan ketentuan pidana terhadap perusahaan angkutan umum yang bukan berbadan hukum kedalam UU LLAJ. Mengingat bahwa pengertian korporasi adalah bagian dari hukum yang terdiri dari korporasi yang badan hukum yang diakui dalam subjek hukum pidana.

\section{Ucapan Terima kasih}

Dalam penelitian ini penulis juga sangat bersyukur karena telah menyelesaikan bagian dari kewajiban penulis, rasa syukur dan terimkakasih itu juga patut dipersembahkan oleh orang-orang yang turut serta dalam penelitian penulis, yaitu Bapak Dhany Eko Prasetyo., SE., SH., ME,M.Hum. Bapak Dr. Prija Djatmika, SH.MS, Ibu Dr. Yuliati, S.H., LL.M, Serta seluruh jajaran pegawai struktural dan non struktural di Pengadilan Negeri Malang. Seluruh upaya dan kerja keras dalam penyusunan dan penyelesaian penelitian ini adalah karena adanya peran dari pada orang-orang yang saya kasihi tersebut.

\section{Daftar Pustaka}

\section{$\underline{\text { Buku }}$}

Arief Amrullah. Politik Hukum Pidana. Yogyakarta: Genta Publishing, 2016.

Barda Nawawi Arief. Kebijakan Hukum Pidana. Jakarta: Kencana Prenadamedia, 2017.

Mahmud Marzuki. Penelitian Hukum. Jakarta: Prenada Media Group, 2015.

Priyatno, Muladi \& Dwidja. Pertanggungjawaban Pidana Korporasi. Ke-3. Jakarta: Kencana Prenada Media Group, 2015.

I Made Pasek Diantha. Metodologi Penelitian Hukum Normatif Dalam Justifikasi Teori Hukum. Jakarta: Prenada Media Group, 2017.

Soejono Soekanto, S. Penelitian Hukum Normatif. Jakarta, Rajawali Pers, 2015.

\section{Jurnal}

Amdani, Yusi. "Formulasi Hukum Pidana Terkait Pertanggung Jawaban Pidana Korporasi Dalam Tindak Pidana Korupsi." Jurnal Hukum Samudra Keadilan 12, no. 2 (2017): 186-98.

Amirullah, Amirullah. "Korporasi Dalam Perspektif Subyek Hukum Pidana." AlDaulah: Jurnal Hukum Dan Perundangan Islam 2, no. 2 (2012): 139-60. https://doi.org/https://doi.org/10.15642/ad.2012.2.2139-160.

Anjari, Warih. "Pertanggungjawaban Korporasi Sebagai Pelaku Tindak Pidana." EJournal Widya Yustisia 1, no. 2 (2018): 116-21.

Bramita, Fifid. "Corporate Criminal Liability On Criminal Actions in Consumer Protection." Jurnal Hukum Novelty 9, no. 2 (2018): 146.

Disemadi, Hari Sutra, and Nyoman Serikat Putra Jaya. "Perkembangan Pengaturan Korporasi Sebagai Subjek Hukum Pidana Di Indonesia." Jurnal Hukum Media Bhakti, 2019. https://doi.org/https://doi.org/10.32501/jhmb.v3i2.38.

Enggarsasi, Umi. "Pertanggung Jawaban Pidana Korporasi Dalam Kejahatan 
$\begin{array}{llllll}\text { Ekonomi." } & \text { Perspektif } & 7, & \text { no. } & 1 & \text { (2006): }\end{array}$

https://doi.org/10.30742/perspektif.v7i1.368.

Fatimah, Fines. "Pertanggungjaw aban Pengganti (Vicarious Liability) Dalam Kebijakan Formulasi Hukum Pidana Di Indonesia." LAW REFORM 7, no. 2 (2012): 1-42. https://doi.org/https://doi.org/10.14710/lr.v7i2.12408.

Feronica, sudirman lu. "Lingkungan Dan Korupsi Korporasi." MIMBAR HUKUM Volume 23, no. 1 (2011). https://doi.org/Doi:org/10.22146/jmh.16190.

Hakim, Lukman. "Implementasi Teori Dualistis Hukum Pidana Di Dalam Rancangan Kitab Undang-Undang Hukum Pidana (RKUHP)." Krtha Bhayangkara 13, no. 1 (2019): 1-16. https://doi.org/https://doi.org/10.31599/krtha.v13i1.12.

Hikmawati, Puteri. "Kendala Penerapan Pertanggungjawaban Pidana Korporasi Sebagai Pelaku Tindak Pidana Korupsi (The Obstacles Of Implementing The Criminal Liability Of The Corporation As A Criminal Of Corruption)." Negara Hukum: Membangun Hukum Untuk Keadilan Dan Kesejahteraan 8, no. 1 (2017): 13150. https://doi.org/10.22212/jnh.v8i1.941.

Juanda, Enju. "Konstruksi Hukum Dan Metode Interpretasi Hukum." Jurnal Ilmiah Galuh Justisi 4, no. 2 (2017): 168. https://doi.org/10.25157/jigj.v4i2.322.

Kristian, Kristian. "Urgensi Pertanggungjawaban Pidana Korporasi." Jurnal Hukum \& Pembangunan 44, no. 4 (December 26, 2014): 575-621. https://doi.org/10.21143/JHP.VOL44.NO4.36.

Prananingrum, Dyah Hapsari. “Telaah Terhadap Esensi Subjek Hukum: Manusia Dan Badan Hukum." Refleksi Hukum: Jurnal Ilmu Hukum 8, no. 1 (2014): 73-92. https://doi.org/https://doi.org/10.24246/jrh.2014.v8.i1.p73-92

Priyatno, Muladi \& Dwidja. Pertanggungjawaban Pidana Korporasi. Ke-3. Jakarta: Kencana Prenada Media Group, 2015.

Putri, F.R., Lie, H., \& Tanlilessy, I.F. "Tindak Pidana Penyuapan Oleh Korporasi Dari Sudut Pandang Teori Identifikasi." Jurnal Hukum Pidana Islam 6, no. 1 (2020). https://doi.org/doi:org/10.15642/aj.2020.6.1.202-228.

Raganatha, Berinda Sylvia. "Tinjauan Pertanggungjawaban Pidana Bagi Korporasi Yang Melakukan Insider Trading Dalam Pasar Modal." Refleksi Hukum: Jurnal Ilmu $\begin{array}{lllll}\text { Hukum 2, no. } & 1 & \text { (2017): }\end{array}$ https://doi.org/https://doi.org/10.24246/jrh.2017.v2.i1.p17-32

Rony Saputra. "Pertanggungjawaban Pidana Korporasi Dalam Tindak Pidana Korupsi." Jurnal Cita Hukum 3, no. 2 (2015). https://doi.org/DOI: 10.15408/jch.v2i2.2318.

Santoso, Agung. "Analisis Kualitas Pelayanan Uji Kir Terhadap Kepuasan Masyarakat Pengguna Jasa Kir Di Dinas Perhubungan Kota Kediri." Jurnal Mediasosian: Jurnal Ilmu Sosial Dan Administrasi Negara 2, no. 1 (2018). https://doi.org/http://dx.doi.org/10.30737/mediasosian.v2i1.206.

Sari, Ratna Kumala, and Nyoman Serikat Putra Jaya. "Kebijakan Formulasi Pertanggungjawaban Pidana Korporasi Terhadap Perbuatan Trading In Influence Sebagai Tindak Pidana Korupsi." Jurnal Pembangunan Hukum Indonesia 2, no. 1 (2020): 12-23. https://doi.org/https://doi.org/10.14710/jphi.v2i1.12-23.

Suhariyanto, Budi. "Putusan Pemidanaan Terhadap Korporasi Tanpa Didakwakan Dalam Perspektif "Vicarious Liability"." Jurnal Yudisial 10, no. 1 (September 8, 2017): 17-38. https://doi.org/10.29123/JY.V10I1.68.

Taun, Taun. "Pertanggungjawaban Pidana Korporasi Dalam Tindak Pidana Ketenagakerjaan." Jurnal IUS Kajian Hukum Dan Keadilan 6, no. 2 (2018): 235-44. https://doi.org/http://dx.doi.org/10.29303/ius.v6i2556. 
Telaumbanua, Dalinama. "Pertanggungjawaban Pidana Korporasi Di Bidang Lingkungan Hidup." Refleksi Hukum: Jurnal Ilmu Hukum 9, no. 1 (2015): 101-12. https://doi.org/https://doi.org/10.24246/jrh.2015.v9.i1.p101-112.

Toruan, Henry Donald Lbn. "Pertanggungjawaban Pidana Korupsi Korporasi." Jurnal Rechts Vinding: Media Pembinaan Hukum Nasional 3, no. 3 (2014): 397-416. https://doi.org/http://dx.doi.org/10.33331/rechtsvinding.v3i3.33.

Wirajaya, A A Ngurah, Nyoman A Martana, Program Kekhususan, Hukum Pidana, Universitas Udayana, and A Latar Belakang. "Asas Tiada Pidana Tanpa Kesalahan (Asas Kesalahan) Dalam Hubungannya Dengan Pertanggungjawaban Pidana Korporasi." Jurnal Kertha Negara 1, no. 3 (2013): 1-5. https://doi.org/Doi.org/10.29123/jym.v20i1.05.

Yuliani, Febri, Andri Andri, Suparwan Cecep Kosasih, Haryono Haryono, Dipo Wahjoeono Hariyono, Magdalena Wullur, Wardaya Wardaya, et al. "Penyelenggaraan Angkutan Orang Dengan Kendaraan Umum Di Surabaya Implementation of Passenger Transport with Public Transport in Surabaya." Jurnal Manajemen Transportasi Dan Logistik 2, no. 2 (2017): 169. 